\title{
Pengaruh Profitabilitas, Ukuran Perusahaan Dan Ukuran Kap Terhadap Audit Delay Pada Perusahaan Properti Dan Real Estate Yang Terdaftar Di Bursa Efek Indonesia Periode 2014-2017
}

\author{
Gusliana Dewi ${ }^{1)}$ \\ Peng $\mathbf{W i}^{2}$ \\ Universitas Buddhi Dharma, Indonesia, Banten
}

\begin{abstract}
ABSTRAK
Ketepatan waktu dalam penyampaian laporan keuangan sangat diperlukan oleh pengguna laporan keuangan untuk bahan pertimbangan dalam pengambilan keputusan. Sebagai perusahaan yang terdaftar di Bursa Efek Indonesia, sesuai dengan ketentuan dari Keputusan Direksi PT. Bursa Efek Jakarta Nomor: Kep-306/BEJ/07-2004 tentang Peraturan Nomor I-E tentang kewajiban penyampaian informasi yang menyebutkan bahwa laporan keuangan tahunan harus disampaikan dalam bentuk laporan keuangan auditan, selambatlambatnya pada akhir bulan ke-3 (ketiga) setelah tanggal laporan keuangan tahunan. Namun masih ditemukan perusahaan yang terlambat dalam menyampaikan laporan keuangannya (audit delay) sehingga mendapatkan sanksi khusus. Penelitian ini bertujuan untuk mengetahui pengaruh profitabilitas, ukuran perusahaan, dan ukuran KAP terhadap audit delay baik secara persial maupun simultan.

Jenis penelitian ini adalah penelitian kuantitatif. Data yang digunakan merupakan data sekunder, yaitu laporan keuangan perusahaan yang terdaftar di Bursa Efek Indonesia (BEI). Populasi pada penelitian ini adalah perusahaan pro perti dan real estate yang terdaftar di Bursa Efek Indonesia periode 2014-2017. Teknik pengambilan sampel yang digunakan adalah teknik purposive sampling, yaitu penentuan sample dengan kreteria tertentu. Diperoleh sampel sebanyak 30 perusahaan, maka banyaknya data yang akan diteliti dalam penelitian ini adalah sebanyak 120 data. Teknik analisis data dalam penelitian ini menggunakan uji statistik deskriptif, uji asumsi klasik, uji koefisien determinasi, analisis regresi linear berganda, uji t, dan uji F yang menggunakan program SPSS (Statistikal Product and Service Solutions) versi 23.0.

Hasil penelitian ini menunjukan bahwa secara persial profitabilitas dan ukuran KAP berpengaruh signifikan terhadap audit delay, namun ukuran perusahaan tidak berpengaruh signifikan terhadap audit delay. Sedangkan secara simultan profitabilitas, ukuran perusahaan dan ukuran KAP berpengaruh terhadap audit delay pada perusahaan properti dan real estate yang terdaftar di Bursa Efek Indonesia periode 2014 - 2017.
\end{abstract}

Kata kunci : Audit Delay, Profitabilitas, Ukuran Perusahaan, Ukuran KAP. 


\title{
THE EFFECT OF PROFITABILITY, FIRM SIZE AND SIZE OF PUBLIC ACCOUNTANT FIRM OF THE AUDIT DELAY IN PROPERTY \& REAL ESTATE COMPANIES LISTED ON THE INDONESIA STOCK EXCHANGE FOR THE PERIOD 2014-2017
}

\begin{abstract}
Timeliness of financial reporting is required by the users of financial statements for consideration in the dicision making. As a company listed on the Indonesia Stock Exchange, in accordance with the provisions of the Decree of the Directors of Jakarta Stock Exchange Number: Kep-306/BEJ/07-2004 concerning Regulation Number I-E concerning the obligation to submit information stating that the annual financial report must be submitted in the form of audited financial reports, no later than the end of the third month after the date annual finance report. However, there are still companies that are late in submitting their financial report (audit delay) so that they get special sanctions. This research aims to determine the effect of profitability, firm size, and size of public accountant firm of the audit delay which is partial and simultaneously.

The type of this research is quantitative research. The data which are used is secondary data from annual financial statement of the companies which is listed on the Indonesia Stock Exchange. The population in this research are property \& real estate companies listed on the Indonesia Stock Exchange for the period 2014-2017. The sampling technique used is proposive sampling technique, which is the determination of samples with certain criteria. The sample of the population in this research is 30 companies, so the amount of data to be examined in this research was 120 data. The data analysis technique in this research uses descriptive statistical tests, classic assumption tests, test coefficient of determination, multiple linear regression analysis, $t$ test, and F test using SPSS program (Statistikal Product and Service Solutions) version 23.

The result of this research shows that the result of parcial profitability and size of public accountant firm have a significant effect on audit delay, however the firm size does not significant effect on audit delay. While simultaneously the profitability, firm size, and size of public accountant firm has a significant effect on audit delay in property \& real estate companies listed on the Indonesia Stock Exchange for the period 2014-2017.
\end{abstract}

Keywords : Audit Delay, Profitability, Firm Size, Size of Public Accountant Firm. 


\section{PENDAHULUAN}

Para investor, kreditor, pemegang saham, dan pihak-pihak lainnya yang terkait dapat mengetahui dan menilai kinerja perusahaan go public dengan melihat laporan keuangan yang dipublikasikan di Bursa Efek Indonesia (BEI) sehingga mereka dapat membuat dan mengambil keputusan ekonomi. Oleh karena itu, untuk menjaga kualitas dari laporan keuangan tersebut, laporan keuangan tahunan wajib disertai dengan laporan akuntan dalam rangka audit atas laporan keuangan.Laporan keuangan yang telah diaudit berarti laporan keuangan telah diverifikasi apakah yang disajikan dalam laporan tersebut sudah sesuai dengan prinsip akuntansi yang berlaku atau belum dan sudah sesuai dengan fakta yang ada.

Penyampaian laporan keuangan tidak terlepas dari proses audit hingga laporan keuangan dan laporan auditor independen dapat di publikasikan kepada pihak eksternal. Periode waktu antara tanggal tahun fiskal laporan keuangan dengan tanggal penandatanganan laporan audit independen mengindikasikan tentang lamanya waktu penyelesaian pekerjaan audit yang dilakukan oleh auditor atau yang sering disebut dengan istilah audit delay.

Kewajiban menyampaikan laporan keuangan dengan tepat waktu ini diatur dalam ketentuan Lampiran Keputusan Ketua Bapepam dan LK nomor: Kep-346/BL/2011 tanggal 5 Juli 2011 yang menyebutkan bahwa laporan keuangan tahunan wajib disampaikan kepada Bapepam dan LK dan diumumkan kepada masyarakat paling lambat pada akhir bulan ketiga setelah tanggal laporan keuangan tahunan. Dan juga adanya ketentuan dari Keputusan Direksi PT. Bursa Efek Jakarta Nomor: Kep-306/BEJ/07-2004 tentang Peraturan Nomor I-E tentang kewajiban penyampaian informasi yang menyebutkan bahwa Laporan keuangan tahunan harus disampaikan dalam bentuk Laporan Keuangan Auditan, selambat-lambatnya pada akhir bulan ke-3 (ketiga) setelah tanggal Laporan Keuangan Tahunan.

Bagi emiten yang terlambat menyerahkan laporan keuangan tahunan akan memperoleh sanksi suspensi atau penghentian sejenak. Berdasarkan Keputusan Direksi PT Bursa Efek Jakarta Nomor: Kep-307/BEJ/07-2004 tentang Peraturan Nomor I-H tentang sanksi khusus perusahaan tercatat yang terlambat menyampaikan laporan keuangan dengan ketentuan sebagai berikut :

1. Peringatan tertulis I, atas keterlambatan penyampaian Laporan Keuangan sampai 30 hari kalender terhitung sejak lampaunya batas waktu penyampaian Laporan keuangan.

2. Peringatan tertulis II dan denda Rp. 50.000.000,-, apabila mulai hari kalender ke 31 hingga hari kalender ke 60 sejak lampaunya batas waktu penyampaian Laporan, perusahaan tercatat tetap tidak memenuhi kewajiban penyampaian Laporan Keuangan.

3. Peringatan tertulis III dan tambahan denda sebesar Rp. 150.000 .000 ,- apabila mulai hari kalender ke 31 hingga hari kalender ke 90 sejak lampaunya batas waktu penyampaian Laporan, perusahaan tercatat tetap tidak memenuhi kewajiban penyampaian Laporan Keuangan atau menyampaikan Laporan Keuangan namun tidak memenuhi kewajiban untuk membayar denda.

4. Suspensi, apabila mulai hari kalender ke-91 sejak lampaunya batas waktu penyampaian Laporan Keuangan dan atau perusahaan tercatat telah menyampaikan Laporan Keuangan namun tidak memenuhi kewajiban untuk membayar denda.

Pada tahun 2014 tercatat 52 emiten yang terlambat menyerahkan laporan keuangan tahunan (neraca.co.id. 2015), tahun 2015 sebanyak 18 emiten (cnnindonesia.com. 2016), dan tahun 2016 sebanyak 17 emiten (m.detik.com.2017).

Sebagai salah satu bentuk perkembangan ekonomi di Indonesia adalah pertumbuhan dan kemajuan perusahaan-perusahaan yang ada di Indonesia. Perusahaan yang semakin bonafit maka akan mengembangkan perusahaannya dengan cara memperkenalkan perusahaannya pada pasar saham, dengan harapan agar lebih banyak investor yang tertarik 
untuk berinvestasi. Hal ini ditandai banyaknya perusahaan yang go public. Perusahaan go public harus terdaftar di Bursa Efek Indonesia (BEI) dengan berbagai peraturan yang berlaku.

Penyampaian laporan keuangan tidak terlepas dari proses audit hingga laporan keuangan dan laporan auditor independen dapat di publikasikan kepada pihak eksternal. Periode waktu antara tanggal tahun fiskal laporan keuangan dengan tanggal penandatanganan laporan audit independen mengindikasikan tentang lamanya waktu penyelesaian pekerjaan audit yang dilakukan oleh auditor atau yang sering disebut dengan istilah audit delay.

Penelitian mengenai audit delay telah banyak dilakukan sebelumnya, namun masih terdapat banyak ketidakkonsistenan dalam hasil penelitian-penelitian terdahulu, sehingga peneliti ingin melakukan penelitian lebih lanjut mengenai tema tersebut untuk mendapatkan hasil yang dapat mendukung hasil penelitian-penelitian sebelumnya. Adapun faktor-faktor yang akan diteliti pada penelitian ini adalah profitabilitas, ukuran perusahaan, dan ukuran KAP.

\section{TINJAUAN PUSTAKA Profitabilitas}

Profitabilitas merupakan rasio yang digunakan untuk mengukur kemampuan perusahaan dalam menghasilkan keuntungan bagi perusahaan yang menunjukkan tingkat keefektivan dan menilai sejauh mana kinerja perusahaan dalam menghasilkan keuntungan bagi investor. Semakin baik rasio profitabilitas maka semakin baik menggambarkan kemampuan tingginya perolehan keuntungan perusahaan.

\section{Ukuran Perusahaan}

Ukuran perusahaan adalah suatu skala dimana dapat diklasifikasikan besar kecilnya perusahaan menurut berbagai cara antara lain dengan total aktiva, log size, nilai pasar saham, dan lain-lain.

\section{Ukuran KAP}

Kantor Akuntan Publik yang selanjutnya disebut KAP, adalah suatu bentuk organisasi akuntan publik yang telah memperoleh izin sesuai dengan peraturan perundang-undangan yang berusaha di bidang pemberian jasa professional dalam praktik akuntan publik. Untuk meningkatkan kredibilitas dari laporan keuangan yang akan disampaikan ke BEI, perusahaan memilih KAP yang memiliki reputasi yang baik. Hal ini biasanya dikaitkan dengan KAP yang berafiliasi dengan KAP Big Four. KAP besar dinilai akan selalu menjaga reputasinya dimata publik, serta dinilai mampu mengerjakan pekerjaan auditnya secara lebih efisien dan efektif sehingga proses audit dapat selesai dengan tepat waktu.

\section{Audit Delay}

Dalam pelakasanaannya auditor diberikan batas waktu untuk menyelesaikan laporan audit independen. Menurut peraturan Bapepam Nomor X.K.2 lampiran keputusan Ketua Bapepam dan LK Nomor: KEP-346/BL/2011 menyatakan bahwa laporan keuangan tahunan wajib disampaikan kepada Bapepam dan LK dan kemudian diumumkan kepada publik paling lambat pada akhir bulan ketiga (atau 90 hari) setelah tanggal laporan keuangan tahunan dikeluarkan. Waktu penyelesaian laporan auditor independen terkadang melewati batas dari waktu yang telah ditetapkan. Hal ini sering disebut dengan istilah audit delay.

\section{Hipotesis Penelitian}

H1 : Profitabilitas memiliki pengaruh yang signifikan terhadap audit delay.

$\mathrm{H} 2$ : Ukuran perusahaan memiliki pengaruh yang signifikan terhadap audit delay.

H3 : Ukuran KAP memiliki pengaruh yang signifikan terhadap audit delay.

H4 : Profitabilitas, ukuran perusahaan, dan ukuran KAP secara bersama-sama memiliki pengaruh yang signifikan terhadap audit delay. 


\section{Populasi dan Sampel}

Populasi yang digunakan dalam penelitian ini adalah perusahaan properti dan real estate yang telah terdaftar di Bursa Efek Indonesia (BEI) pada tahun 2014-2017. Dalam pemilihan sampel ini, peneliti menggunakan metode purposive sampling yang termasuk dalam teknik non random sampling dimana pengambilan sampel tidak semua anggota populasi diberi kesempatan untuk dipilih menjadi sampel. Teknik pengambilan sampel dengan metode ini dilakukan berdasarkan pertimbangan dan kriteria tertentu agar dapat memperoleh sumber data yang tepat dan sesuai dengan variabel yang diteliti agar dapat mewakili suatu populasi.

Sampel yang dipilih dalam penelitian ini adalah perusahaan properti dan real estate yang terdaftar di Bursa Efek Indonesia dengan kriteria sebagai berikut:

1. Perusahaan berturut-turut terdaftar di Bursa Efek Indonesia sebagai perusahaan properti dan real estate pada tahun 2014-2017.

2. Perusahaan menerbitkan laporan keuangan per 31 Desember selama periode pengamatan yaitu pada tahun 2014-2017.

3. Perusahaan yang laporan keuangannya menunjukan laba berturut-turut selama tahun 2014-2017.

4. Perusahaan mengeluarkan laporan audit independen atas laporan keuangan.

5. Perusahaan menerbitkan laporan keuangan dengan menggunakan mata uang fungsional rupiah.

\section{Teknik Pengumpulan Data}

Teknik pengumpulan data pada penelitian ini dilakukan dengan 2 metode :

1. Metode kepustakaan adalah metode pengumpulan data dengan menggunakan buku referensi atau literatur yang berkaitan dengan masalah yang diteliti. Kepustakaan dilakukan dengan cara mengumpulkan dan membaca buku referensi dan literature serta bahan pustaka lainnya seperti jurnal, buku dan penelitian terdahulu yang terkait dengan variabel-variabel yang ada dalam penelitian ini. Metode ini digunakan untuk mendapatkan landasan teori yang tepat dan sesuai dengan pembahasan dalam penelitian ini.

2. Metode dokumentasi, dimana pengumpulan data berupa laporan keuangan setiap sampel selama tahun 2014-2017 dengan sumber laporan keuangan yang dipublikasikan oleh website resmi BEI yaitu www.idx.co.id.

\section{Operasionalisasi Variabel Penelitian \\ Variabel Dependen (Y)}

Variabel dependen (variabel terikat) adalah variabel yang dipengaruhi atau yang menjadi akibat, karena adanya variabel independen (variabel bebas). Variabel dependen dalam penelitian ini yaitu audit delay. Audit delay adalah lamanya waktu yang dibutuhkan auditor untuk menyelesaikan pekerjaan auditnya, yang diukur dari tanggal penutupan tahun buku perusahaan hingga tanggal diterbitkannya laporan keuangan audit independen. Audit delay diukur secara kuantitatif dalam jumlah hari.

Audit Delay = Tanggal diterbitkan laporan audit - Tanggal penutupan tahun buku

\section{Variabel Independen $(X)$}

Variable independen (variabel bebas) merupakan jenis variabel yang menjelaskan atau mempengaruhi variabel lain. 
a. Profitabilitas

Profitabilitas merupakan rasio yang digunakan untuk mengukur kemampuan perusahaan dalam menghasilkan keuntungan bagi perusahaan yang menunjukkan tingkat keefektivan dan menilai sejauh mana kinerja perusahaan dalam menghasilkan keuntungan bagi investor. Dalam penelitian ini, profitabilitas diukur dengan menggunakan ROA (Return On Asset). Rumus untuk menghitung ROA adalah sebagai berikut :

$\mathrm{ROA}=\frac{\text { Laba bersih (EAIT) }}{\text { Total Aset }} \times 100 \%$

b. Ukuran Perusahaan

Ukuran perusahaan dapat menggambarkan besar kecilnya suatu perusahaan yang ditunjukkan oleh total aktiva, jumlah penjualan, rata-rata total penjualan dan rata-rata total aktiva. Oleh karena itu, ukuran perusahaan merupakan ukuran besarnya aset yang dimiliki oleh perusahaan. Ukuran perusahaan dalam penelitian ini diukur melalui logaritma natural total aset. Total aset dijadikan alat pengukuran ukuran perusahaan karena nilai aset lebih stabil dibandingkan dengan nilai penjualan yang cenderung naik/turun. Rumus untuk mengukur ukuran perusahaan adalah sebagai berikut :

Ukuran Perusahaan $=$ Ln $($ Total Aset $)$

c. Ukuran KAP

Dalam meningkatkan kredibilitas dari laporan keuangan, perusahaan memilih KAP yang memiliki reputasi yang baik. Hal ini biasanya dikaitkan dengan KAP yang berafiliasi dengan KAP Big Four. Dalam penelitian ini, ukuran KAP diukur dengan variabel dummy, dimana kategori 1 dimaksudkan untuk perusahaan yang menggunakan KAP yang berafiliasi dengan Big Four, sedangkan kategori 0 dimaksudkan untuk perusahaan yang menggunakan KAP yang berafiliasi dengan Non Big Four.

$$
\text { ROA }=\frac{\text { Laba bersih (EAIT) }}{\text { Total Aset }} \times 100 \%
$$

\section{ANALISA DAN PEMBAHASAN}

Hasil Analisis Statistik Deskriptif Descriptive Statistics

\begin{tabular}{|l|r|r|r|r|r|}
\hline & $\mathrm{N}$ & Minimum & Maximum & \multicolumn{1}{c|}{ Mean } & \multicolumn{1}{c|}{ Std. } \\
& \multicolumn{1}{|c|}{ Deviation } \\
\hline Audit Delay & 120 & 40.00 & 116.00 & 74.7833 & 15.93326 \\
Profitabilitas & 120 & .03 & 19.27 & 6.2602 & 4.63740 \\
Ukuran Perusahaan & 120 & 12.08 & 17.85 & 15.5932 & 1.21575 \\
Ukuran KAP & 120 & .00 & 1.00 & .2667 & .44407 \\
Valid N (listwise) & 120 & & & & \\
\hline
\end{tabular}

Sumber : Data Diolah Menggunakan SPSS Versi 23, 2018

Setelah dilakukan analisis statistik deskriptif dengan menggunakan SPSS versi 23, maka hasil output menunjukan jumlah sampel perusahaan sebanyak 120, nilai minimum, 
maksimum, mean dan standard deviasi dari variabel audit delay, profitabilitas, ukuran perusahaan dan ukuran KAP. Jika dijabarkan sebagai berikut :

Variabel audit delay terdapat nilai minimum sebesar 40 yang dimiliki oleh Bumi Serpong Damai Tbk., nilai 116 merupakan nilai maksimum dimiliki oleh Agung Podomoro Land Tbk., nilai rata-rata dari variabel audit delay adalah 74.7833 , nilai standard deviasi sebesar 15.93326. Hal ini menyatakan bahwa Bumi Serpong Damai Tbk. sangat disiplin dalam penyampaian laporan keuangannya ke Bursa Efek Indonesia, sedangkan Agung Podomoro Land Tbk. walaupun terbilang perusahaan yang besar, namun ada kalanya menjadi perusahaan yang melakukan keterlambatan paling lama dalam penyampaian laporan keuangan ke Bursa Efek Indonesia selama tahun 2014-2017.

Variabel profitabilitas pada tabel diatas menunjukan tingkat rasio kinerja perusahaan dalam menghasilkan keuntungan dari asset dengan rasio minimum $0.03 \%$ milik Gading Development Tbk., rasio maksimum dimiliki oleh Lippo Cikarang Tbk. dengan rasio sebesar $19.27 \%$, nilai 6.2602 merupakan nilai rata-rata, dan nilai 4.63740 merupakan nilai standard deviasi. Hal ini menunjukkan bahwa masih ada perusahaan yang belum mampu memberikan keuntungan atau kekayaan maksimal terhadap investornya, dalam penelitian ini adalah Gading Development Tbk., sedangkan Lippo Cikarang Tbk. sebagai pemilik rasio maksimum pada penelitian ini memperlihatkan kemampuan perusahaan dalam memberikan persepsi positif terhadap investor dan mampu memberikan kemakmuran terhadap pemegang sahamnya. Dari nilai standar deviasi sebesar 4.63740 yang berarti lebih kecil dari nilai rataratanya sebesar 6.2602 menunjukan bahwa sebaran data untuk profitabilitas adalah baik.

Variabel ukuran perusahaan dalam penelitian ini ditunjukkan dengan total aktiva perusahaan karena total aktiva perusahaan merupakan salah satu petunjuk kekayaan perusahaan. Ukuran perusahaan diukur dari Logaritma natural dari total aset dengan tujuan untuk menyederhanakan perhitungan. Pada penelitian ini variabel ukuran perusahaan memiliki nilai minimum sebesar 12.08 yang merupakan nilai Logaritma natural total aset dari perusahaan Bekasi Asri Pemula Tbk. pada tahun 2014. Artinya total aset perusahaan Bekasi Asri Pemula Tbk. tahun 2014 adalah total aset terkecil dibandingkan dengan perusahaan sampel lainnya. Sedangkan nilai Logaritma natural total aset dari perusahaan Lippo Karawaci Tbk. pada tahun 2017 sebesar 17.85 adalah nilai maksimum variabel ukuran perusahaan. Artinya adalah total aset perusahaan Lippo Karawaci Tbk. pada tahun 2017 merupakan total aset terbesar dari perusahaan sampel lainnya. Dari nilai standar deviasi sebesar 1.21575 yang berarti lebih kecil dari nilai rata- ratanya sebesar 15.5932 menunjukan bahwa sebaran data untuk ukuran perusahaan baik.

Variabel ukuran KAP merupakan variabel dummy dimana memiliki nilai minimum sebesar 0 yang merupakan katagori untuk perusahaan yang menggunakan KAP kecil yang diukur dengan KAP yang tidak berafiliasi dengan KAP Big Four, sedangkan nilai maksimum sebesar 1 yang merupakan katagori untuk perusahaan yang menggunakan KAP besar yang diukur dengan KAP yang berafiliasi dengan KAP Big Four. 


\section{Uji Asumsi Klasik}

\section{Uji Normalitas}

\section{Hasil Uji Normalitas Grafik P-Plot}

Normal P-P Plot of Regression Standardized Residual

Dependent Variable: Audit Delay

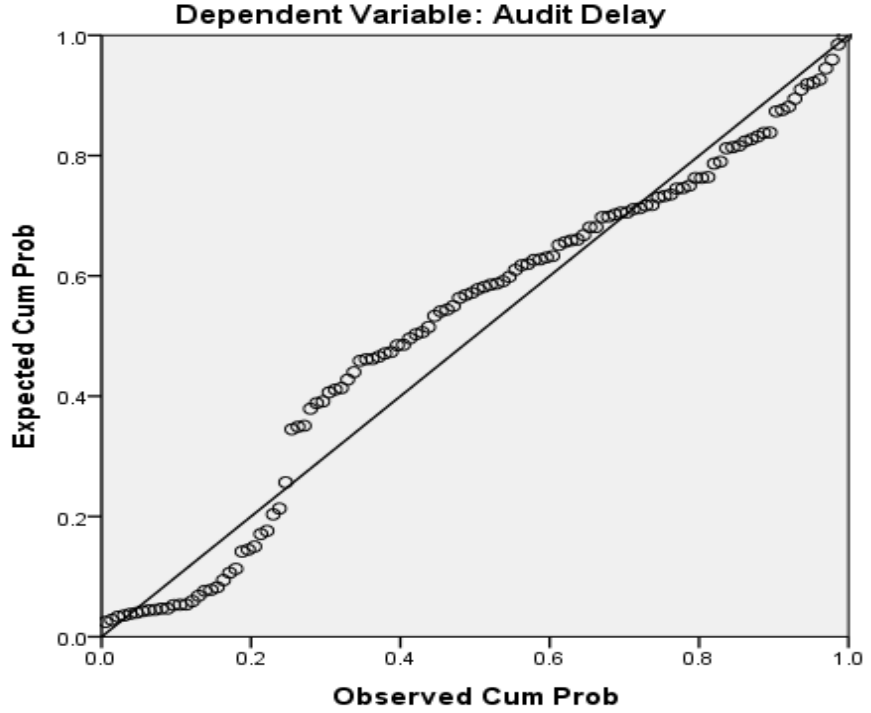

Sumber : Data diolah menggunakan SPSS 23, 2018

Dari gambar diatas bisa dilihat bahwa data yang diteliti menyebar disekitar garis diagonal dan mengikuti arah diagonal. Dengan kondisi tersebut dapat disimpulkan bahwa model regresi yang diteliti memenuhi asumsi normalitas.

\section{Uji Multikolonieritas}

\section{Hasil Uji Multikolonieritas \\ Coefficients $^{\mathrm{a}}$}

\begin{tabular}{|ll|r|r|}
\hline \multirow{2}{*}{ Model } & \multicolumn{2}{|c|}{ Collinearity Statistics } \\
\cline { 2 - 3 } 1 & Tolerance & \multicolumn{1}{|c|}{ VIF } \\
\hline & (Constant) & & \\
& Profitabilitas & .988 & 1.013 \\
& Ukuran Perusahaan & .907 & 1.102 \\
\multicolumn{2}{|l|}{ Ukuran KAP } & .907 & 1.103 \\
\hline
\end{tabular}

a. Dependent Variable: Audit Delay

Sumber : Data Diolah Menggunakan SPSS Versi 23, 2018

Berdasarkan hasil pengolahan tersebut dapat dilihat bahwa nilai VIF pada semua variabel independen dibawah angka 10 yaitu profitabilitas sebesar 1.013, ukuran perusahaan sebesar 1.102, dan ukuran KAP sebesar 1.103, sedangkan untuk nilai tolerance pada semua variabel independen adalah lebih besar dari 0.10 yaitu profitabilitas sebesar 0.988 , ukuran perusahaan sebesar 0.907 , dan ukuran KAP sebesar 0.907. Sehingga dapat dinyatakan bahwa model regresi bebas dari multikolonieritas. Hal ini menjelaskan bahwa tidak ada korelasi yang signifikan antara masing-masing variabel independen. 


\section{Uji Heteroskedastisitas}

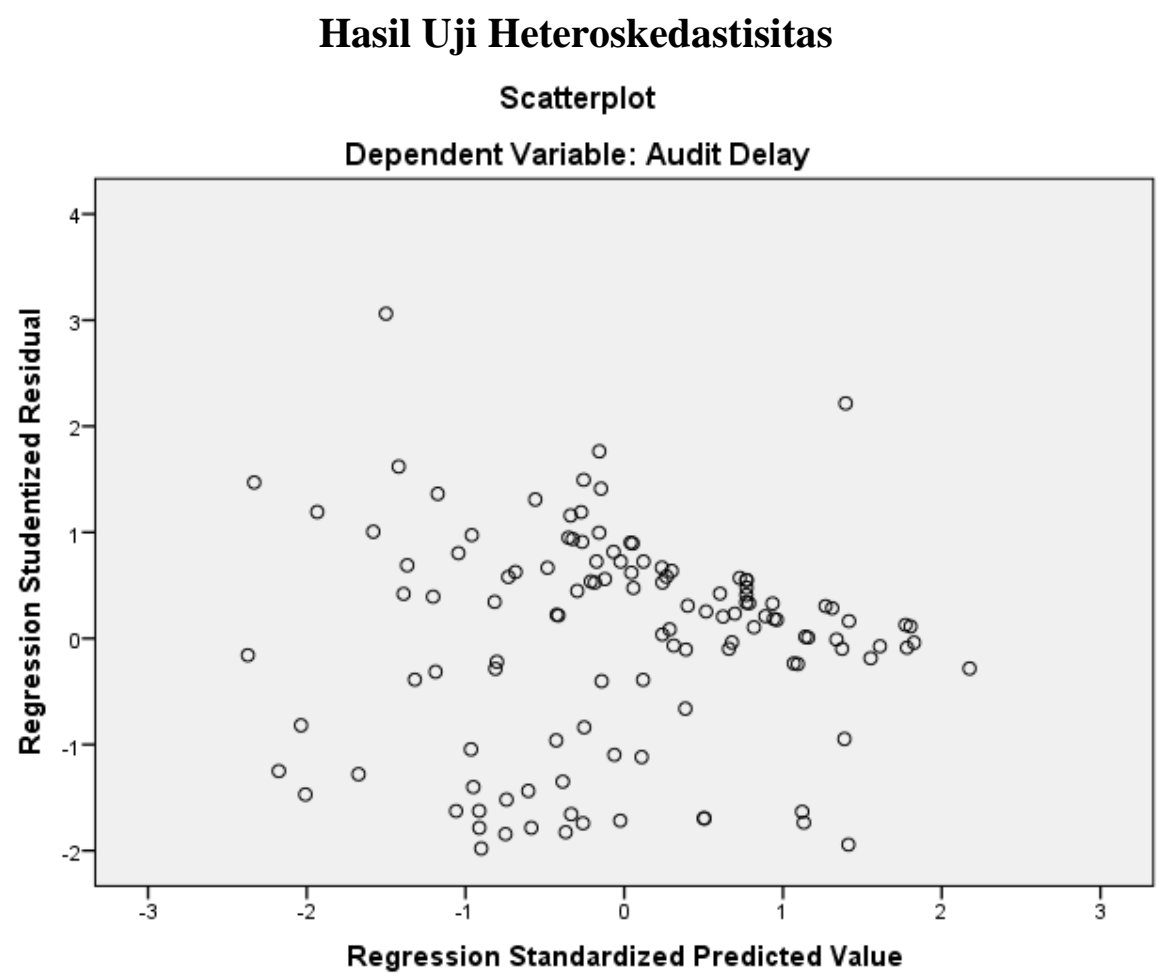

Sumber : Data Diolah Menggunakan SPSS Versi 23, 2018

Berdasarkan hasil dari scatterplot diatas tampak bahwa scatterplot antara SRESID dan ZPRED yang terbentuk menyebar tidak memiliki pola tertentu atau menyebar dibagian atas dan bagian bawah angka 0 pada sumbu $Y$ dan $n$ di kanan dan kiri pada sumbu X. hal ini menunjukkan bahwa model regresi ini tidak terjadi hubungan antara variabel bebas dan nilai residual. Dengan begitu asumsi non heteroskedastisitas model regresi ini terpenuhi.

\section{Uji Autokorelasi}

\section{Hasil Uji Autokorelasi} Model Summary ${ }^{b}$

\begin{tabular}{|l|c|r|r|r|r|}
\hline Model & R & R Square & Adjusted R Square & $\begin{array}{c}\text { Std. Error of the } \\
\text { Estimate }\end{array}$ & Durbin-Watson \\
\hline 1 & $.439^{\mathrm{a}}$ & .193 & .172 & 14.49870 & 1.243 \\
\hline
\end{tabular}

a. Predictors: (Constant), Ukuran KAP, Profitabilitas, Ukuran Perusahaan

b. Dependent Variable: Audit Delay

Sumber : Data Diolah Menggunakan SPSS Versi 23, 2018

Hasil output dengan jumlah sampel (n) sebesar 120 dan jumlah variabel independen (k) sebanyak 3 maka diperoleh nilai D-W sebesar 1.243 yang mana terletak antara -2 sampai +2 , yang berarti tidak adanya autokorelasi. 
Uji Koefisien Determinasi $\left(R^{2}\right)$

Hasil Uji Koefisien Determinasi $\left(\mathbf{R}^{2}\right)$

Model Summary ${ }^{\mathrm{b}}$

\begin{tabular}{|l|c|c|c|c|r|}
\hline Model & $\mathrm{R}$ & $\begin{array}{c}\mathrm{R} \\
\text { Square }\end{array}$ & Adjusted R Square & $\begin{array}{c}\text { Std. Error of the } \\
\text { Estimate }\end{array}$ & Durbin-Watson \\
\hline 1 & $.439^{\mathrm{a}}$ & .193 & .172 & 14.49870 & 1.243 \\
\hline
\end{tabular}

a. Predictors: (Constant), Ukuran KAP, Profitabilitas, Ukuran Perusahaan

b. Dependent Variable: Audit Delay

Sumber : Data Diolah Menggunakan SPSS Versi 23, 2018

Dari tampilan output SPSS model summary dapat dilihat bahwa nilai Adjusted $\mathrm{R}$ Square sebesar 0.172. Karena nilai tersebut mendekati nol maka hal ini berarti kemampuan variabel independen (profitabilitas, ukuran perusahaan dan ukuran KAP) cukup lemah dalam menjelaskan variabel dependen (audit delay). Hanya 17,20\% variabel dependen dapat dijelaskan oleh variabel independen, sedangkan sisanya $82,80 \%$ dijelaskan oleh variabel diluar dari model. Hubungan ini dapat dijabarkan lebih lanjut sebagai berikut :

\section{Hasil Uji Koefisien Determinasi \\ (Variabel Profitabilitas Terhadap Audit Delay) Model Summary ${ }^{\mathrm{b}}$}

\begin{tabular}{|l|l|r|r|r|r|}
\hline Model & $\mathrm{R}$ & $\begin{array}{c}\mathrm{R} \\
\text { Square }\end{array}$ & Adjusted R Square & $\begin{array}{c}\text { Std. Error of the } \\
\text { Estimate }\end{array}$ & Durbin-Watson \\
\hline 1 & $.284^{\mathrm{a}}$ & .081 & .073 & 15.34059 & 1.182 \\
\hline
\end{tabular}

a. Predictors: (Constant), Profitabilitas

b. Dependent Variable: Audit Delay

Sumber : Data Diolah Menggunakan SPSS Versi 23, 2018

Dari tampilan output SPSS di atas dapat dilihat bahwa nilai R Square sebesar 0.081. Karena nilai tersebut mendekati nol maka hal ini berarti kemampuan variabel profitabilitas cukup lemah dalam menjelaskan variabel audit delay. Hanya 8,10\% variabel audit delay dapat dijelaskan oleh variabel profitabilitas, sedangkan sisanya 91,90\% dijelaskan oleh variabel lain.

\section{Hasil Uji Koefisien Determinasi \\ (Variabel Ukuran Perusahaan Terhadap Audit Delay) \\ Model Summary ${ }^{\text {b }}$}

\begin{tabular}{|l|r|r|r|r|r|}
\hline $\begin{array}{l}\text { Mod } \\
\text { el }\end{array}$ & $\mathrm{R}$ & R Square & Adjusted R Square & $\begin{array}{c}\text { Std. Error of the } \\
\text { Estimate }\end{array}$ & Durbin-Watson \\
\hline 1 & $.038^{\mathrm{a}}$ & .001 & -.007 & 15.98902 & 1.121 \\
\hline
\end{tabular}

a. Predictors: (Constant), Ukuran Perusahaan

b. Dependent Variable: Audit Delay

Sumber : Data Diolah Menggunakan SPSS Versi 23, 2018

Dari tampilan output SPSS di atas dapat dilihat bahwa nilai R Square sebesar 0.038. Karena nilai tersebut mendekati nol maka hal ini berarti kemampuan variabel ukuran perusahaan cukup lemah dalam menjelaskan variabel audit delay. Hanya 3,80\% variabel audit delay dapat dijelaskan oleh variabel ukuran perusahaan, sedangkan sisanya 96,20\% dijelaskan oleh variabel lain. 
AKUNTOTEKNOLOGI : JURNAL ILMIAH AKUNTANSI DAN TEKNOLOGI - VOL. 10. No. 1 (2018)

Versi Online Tersedia di : https://jurnal.ubd.ac.id/index.php/akunto

| 2085-8108 (Cetak) | 2541-3503 (Online) |

\section{Hasil Uji Koefisien Determinasi \\ (Variabel Ukuran KAP Terhadap Audit Delay)} Model Summary ${ }^{\mathrm{b}}$

\begin{tabular}{|l|l|r|r|r|r|}
\hline $\begin{array}{l}\text { Mode } \\
1\end{array}$ & $\mathrm{R}$ & R Square & Adjusted R Square & $\begin{array}{c}\text { Std. Error of the } \\
\text { Estimate }\end{array}$ & Durbin-Watson \\
\hline 1 & $.289^{\mathrm{a}}$ & .083 & .075 & 15.32016 & 1.154 \\
\hline
\end{tabular}

a. Predictors: (Constant), Ukuran KAP

b. Dependent Variable: Audit Delay

Sumber : Data Diolah Menggunakan SPSS Versi 23, 2018

Dari tampilan output SPSS di atas dapat dilihat bahwa nilai R Square sebesar 0,289. Karena nilai tersebut mendekati nol maka hal ini berarti kemampuan variabel ukuran KAP cukup lemah dalam menjelaskan variabel audit delay. Hanya 28,90\% variabel audit delay dapat dijelaskan oleh variabel ukuran KAP, sedangkan sisanya 71,10\% dijelaskan oleh variabel lain.

\section{Analisis Regresi Linier Berganda}

\section{Hasil Analisis Regresi Linier Berganda}

Coefficients $^{\mathrm{a}}$

\begin{tabular}{|c|c|c|c|c|c|c|c|}
\hline \multirow[b]{2}{*}{ Model } & \multicolumn{2}{|c|}{$\begin{array}{c}\text { Unstandardized } \\
\text { Coefficients }\end{array}$} & \multirow{2}{*}{$\begin{array}{c}\begin{array}{c}\text { Standardized } \\
\text { Coefficients }\end{array} \\
\text { Beta } \\
\end{array}$} & \multirow[b]{2}{*}{$\mathrm{t}$} & \multirow[b]{2}{*}{ Sig. } & \multicolumn{2}{|c|}{$\begin{array}{l}\text { Collinearity } \\
\text { Statistics }\end{array}$} \\
\hline & B & $\begin{array}{l}\text { Std. } \\
\text { Error }\end{array}$ & & & & $\begin{array}{l}\text { Toleran } \\
\text { ce }\end{array}$ & VIF \\
\hline $1 \quad$ (Constant) & $\begin{array}{r}101.70 \\
6\end{array}$ & 17.688 & & 5.750 & .000 & & \\
\hline Profitabilitas & -1.053 & .288 & -.306 & $\begin{array}{r}- \\
3.650\end{array}$ & .000 & .988 & 1.013 \\
\hline $\begin{array}{l}\text { Ukuran } \\
\text { Perusahaan }\end{array}$ & -1.520 & 1.148 & -.116 & 1.324 & .188 & .907 & 1.102 \\
\hline Ukuran KAP & 12.603 & 3.143 & .351 & 4.010 & .000 & .907 & 1.103 \\
\hline
\end{tabular}

a. Dependent Variable: Audit Delay

Sumber : Data Diolah Menggunakan SPSS Versi 23, 2018

Berdasarkan hasil olahan SPSS pada gambar coefficient diatas diperoleh persamaan regresi sebagai berikut :

$\mathrm{AD}=101.706-1.053$ Profitabilitas -1.520 Ukuran Perusahaan +12.603 Ukuran KAP $+\mathrm{e}$

1. Konstanta

Nilai konstanta sebesar positif 101.706 mempunyai arti bahwa jika semua variabel

independen (profitabilitas, ukuran perusahaan dan ukuran KAP) konstant atau bernilai 0, maka nilai variabel dependen yaitu audit delay sebesar 101.706.

2. Profitabilitas

Nilai profitabilitas (X1) memiliki koefisien regresi sebesar -1.053. Hal ini menunjukan bahwa profitabilitas berpengaruh negatif terhadap audit delay, sehingga dapat disimpulkan bahwa semakin besar keuntungan yang didapat suatu perusahaan maka audit delay akan cenderung menurun sebesar 1.053.

3. Ukuran Perusahaan

Nilai koefisien ukuran perusahaan (X2) memiliki koefisien regresi sebesar 1.520. Hal ini menunjukan bahwa ukuran perusahaan berpengaruh negatif terhadap audit delay, 
sehingga dapat disimpulkan bahwa semakin besar ukuran suatu perusahaan maka audit delay akan mengalami penurunan sebesar 1.520.

4. Ukuran KAP

Nilai koefisien ukuran KAP (X3) memiliki koefisien regresi sebesar positif 12.603. Hal ini menunjukan bahwa ukuran perusahaan berpengaruh positif terhadap audit delay, sehingga dapat disimpulkan bahwa semakin besar ukuran KAP maka audit delay akan meningkat sebanyak 12.603 .

Uji Signifikan Perimeter Individual (Uji Statistik t)

Hasil Uji t

Coefficients $^{\mathrm{a}}$

\begin{tabular}{|c|c|c|c|c|c|c|c|}
\hline \multirow[b]{2}{*}{ Model } & \multicolumn{2}{|c|}{$\begin{array}{c}\text { Unstandardized } \\
\text { Coefficients }\end{array}$} & \multirow{2}{*}{$\begin{array}{c}\begin{array}{c}\text { Standardize } \\
\mathrm{d} \\
\text { Coefficients }\end{array} \\
\text { Beta }\end{array}$} & \multirow[b]{2}{*}{$\mathrm{t}$} & \multirow[b]{2}{*}{ Sig. } & \multicolumn{2}{|c|}{$\begin{array}{c}\text { Collinearity } \\
\text { Statistics }\end{array}$} \\
\hline & B & Std. Error & & & & $\begin{array}{l}\text { Toleran } \\
\text { ce }\end{array}$ & VIF \\
\hline $1 \quad$ (Constant) & 101.706 & 17.688 & & 5.750 & .000 & & \\
\hline Profitabilitas & -1.053 & .288 & -.306 & $3.650^{-}$ & .000 & .988 & 1.013 \\
\hline $\begin{array}{l}\text { Ukuran } \\
\text { Perusahaan }\end{array}$ & -1.520 & 1.148 & -.116 & $1.324^{-}$ & .188 & .907 & 1.102 \\
\hline Ukuran KAP & 12.603 & 3.143 & .351 & 4.010 & .000 & .907 & 1.103 \\
\hline
\end{tabular}

a. Dependent Variable: Audit Delay

Sumber : Data Diolah Menggunakan SPSS Versi 23, 2018

a. Pengaruh profitabilitas terhadap audit delay

Ho : Profitabilitas tidak berpengaruh signifikan terhadap audit delay.

Ha : Profitabilitas berpengaruh signifikan terhadap audit delay.

Berdasarkan hasil pengujian diatas dapat dilihat bahwa nilai t hitung sebesar 3,650 lebih besar dari nilai t tabel sebesar 1,658 $(3,650>1,658)$ dan memiliki nilai signifikan 0,000 nilai ini tentu lebih kecil dari nilai signifikan yang telah ditetapkan yaitu $0,05(0,000<$ 0,05). Diperkuat dengan tingkat keyakinannya sebesar 100,\% (100\% - 0\%). Dengan demikian Ho ditolak dan Ha (hipotesis yang diajukan dalam peneltian/H1) diterima. Hal ini menunjukan bahwa profitabilitas berpengaruh terhadap audit delay.

b. Pengaruh ukuran perusahan terhadap audit delay

Ho : Ukuran perusahaan tidak berpengaruh signifikan terhadap audit delay.

Ha : Ukuran perusahaan berpengaruh signifikan terhadap audit delay.

Berdasarkan hasil pengujian diatas dapat dilihat bahwa nilai t hitung sebesar 1,324 lebih kecil dari nilai t tabel sebesar 1,658 $(1,324<1,658)$ dan memiliki nilai signifikan 0,188 yang lebih besar dari nilai signifikan yang telah ditetapkan yaitu $0,05(0,188>0,05)$. Diperkuat dengan tingkat keyakinannya sebesar 18,8\% (100\% - 18,8\%) dan sisanya sebesar $81,2 \%$ dipengaruhi oleh faktor-faktor lain. Dengan demikian Ho diterima dan $\mathrm{Ha}$ (hipotesis yang diajukan dalam peneltian/H2) ditolak. Hal ini menunjukan bahwa ukuran perusahaan tidak berpengaruh terhadap audit delay.

c. Pengaruh ukuran KAP terhadap audit delay

Ho : Ukuran KAP tidak berpengaruh signifikan terhadap audit delay.

Ha : Ukuran KAP berpengaruh signifikan terhadap audit delay. 
Berdasarkan hasil pengujian diatas dapat dilihat bahwa nilai t hitung sebesar 4,010 lebih besar dari nilai t tabel sebesar $1,658(4,010>1,658)$ dan memiliki nilai signifikan 0,000 nilai ini tentu lebih kecil dari nilai signifikan yang telah ditetapkan yaitu $0,05(0,000<$ 0,05). Diperkuat dengan tingkat keyakinannya sebesar 100,\% (100\% - 0\%). Dengan demikian Ho ditolak dan Ha (hipotesis yang diajukan dalam peneltian/H2) diterima. Hal ini menunjukan bahwa Ukuran KAP berpengaruh signifikan terhadap audit delay.

\section{Uji Signifikansi Keseluruhan dari Regresi Sample (Uji Statistik F)}

\section{Hasil Uji F}

ANOVA $^{\mathrm{a}}$

\begin{tabular}{|ll|r|r|r|r|r|}
\hline \multicolumn{2}{|l|}{ Model } & \multicolumn{1}{c|}{$\begin{array}{c}\text { Sum of } \\
\text { Squares }\end{array}$} & \multicolumn{1}{c|}{ df } & Mean Square & F & Sig. \\
\hline 1 & Regression & 5825.751 & 3 & 1941.917 & 9.238 & $.000^{\mathrm{b}}$ \\
& Residual & 24384.616 & 116 & 210.212 & & \\
& Total & 30210.367 & 119 & & & \\
\hline
\end{tabular}

a. Dependent Variable: Audit Delay

b. Predictors: (Constant), Ukuran KAP, Profitabilitas, Ukuran Perusahaan

Sumber : Data Diolah Menggunakan SPSS Versi 23, 2018

Dari tabel tersebut menunjukkan bahwa nilai signifikansi 0.000 yang bernilai kurang dari $0.05(0,000<0,05)$ dan $\mathrm{F}$ hitung sebesar 9,238 yang mana lebih besar dari pada $\mathrm{F}$ tabel 2,68 $(9,238>2,68)$ maka Ho ditolak dan Ha diterima. Maka dapat disimpulkan bahwa profitabilitas, ukuran perusahaan dan ukuran KAP secara bersama-sama (simultan) berpengaruh signifikan terhadap audit delay.

\section{PEMBAHASAN}

\section{Pengaruh Profitabilitas terhadap Audit Delay}

Berdasarkan hasil pengujian hipotesis yang dilakukan menunjukan bahwa profitabilitas berpengaruh signifikan terhadap audit delay. Hal ini dapat dilihat dari tingkat signifikansi profitabilitas sebesar 0.00 dimana lebih kecil dari 0.05 dan bila dibandingkan nilai $\mathrm{t}$ hitung sebesar 3,650 lebih besar dari nilai t tabel sebesar 1,658. Profitabilitas yang diukur dengan Return On Asset (ROA) tepat digunakan sebagai acuan dalam pengukuran audit delay. Dengan demikian hipotesis yang diajukan dalam peneltian (H1) diterima. Hasil penelitian ini mendukung penelitian sebelumnya yang dilakukan oleh Zwaztiana dan Suzan (2018) yang menyatakan bahwa profitabilitas yang diukur dengan ROA mempengaruhi audit delay.

\section{Pengaruh Ukuran Perusahaan terhadap Audit Delay}

Berdasarkan hasil pengujian variabel ukuran perusahaan memiliki tingkat signifikansi sebesar 0.188 dimana lebih besar dari 0.05 dan nilai t hitung sebesar 1,324 lebih kecil dari nilai $\mathrm{t}$ tabel sebesar 1,658. Maka dapat disimpulkan bahwa ukuran perusahaan tidak berpengaruh terhadap audit delay. Hal ini menyatakan bahwa besar kecilnya perusahaan tetap harus memperhatikan ketepatan waktu dalam penyampaian laporan keuangan ke Bursa Efek Indonesia agar dapat menjadi daya tarik investor dan juga terhindar dari sanksi atas keterlambatan penyampaian laporan keuangan. Dengan demikian hipotesis yang diajukan dalam penelitian (H2) ditolak. Hasil penelitian ini mendukung penelitian sebelumnya yang dilakukan oleh Eksandy (2017) yang menyatakan bahwa ukuran perusahaan tidak berpengaruh terhadap audit delay. 


\section{Pengaruh Ukuran KAP terhadap Audit Delay}

Berdasarkan hasil pengujian diatas variabel ukuran KAP memiliki tingkat signifikansi sebesar 0.00 dimana lebih kecil dari 0.05 dan nilai thitung sebesar 4,010 lebih besar dari nilai $\mathrm{t}$ tabel sebesar 1,658. Hal ini menunjukan bahwa ukuran KAP berpengaruh signifikan terhadap audit delay. Dengan memilih KAP yang memiliki reputasi yang baik, maka dapat meminimalisir terjadinya keterlambatan dalam penyampaian laporan keuangan ke Bursa Efek Indonesia. Dengan demikian hipotesis yang diajukan dalam peneltian (H3) diterima. Hasil penelitian ini mendukung penelitian sebelumnya oleh Hastuti dan Santoso (2017) yang menyatakan bahwa ukuran KAP berpengaruh terhadap audit delay.

4. Pengaruh Profitabilitas, Ukuran Perusahaan dan Ukuran KAP terhadap Audit Delay Berdasarkan hasil uji signifikansi menunjukkan bahwa nilai signifikansi 0.000 yang bernilai kurang dari 0.05 yang merupakan batas signifikansi, dan F hitung sebesar 9,238 yang mana lebih besar dari pada $F$ tabel 2,68 sehingga hipotesis yang diajukan dalam peneltian (H4) diterima. Hal ini didukung pula oleh hasil uji koefisien determinasi yang memperoleh nilai Adjusted R Square sebesar 0.172 atau 17,20\% yang berarti bahwa profitabilitas, ukuran perusahaan dan ukuran KAP secara simultan dapat menentukan besarnya perubahan audit delay pada perusahaan properti dan real estate periode tahun 2014-2017 sedangkan 82,80\% dipengaruhi oleh faktor lain yang tidak dibahas dalam penelitian ini. Hasil penelitian ini sesuai dengan penelitian dari yang dilakukan oleh Nurahman Apriyana (2017) yang hasil penelitiannya menyatakan bahwa profitabilitas, ukuran perusahaan dan ukuran KAP secara bersama-sama (simultan) berpengaruh terhadap audit delay.

\section{KESIMPULAN}

Penelitian ini bertujuan untuk menguji pengaruh profitabilitas, ukuran perusahaan dan ukuran KAP terhadap audit delay. Sampel yang digunakan dalam penelitian ini sebanyak 30 perusahaan properti dan real estate yang terdaftar di Bursa Efek Indonesia selama periode tahun 2014-2017. Dari hasil analisis dan pengujian yang telah diterapkan maka dapat ditarik kesimpulan bahwa :

1. Profitabilitas berpengaruh signifikan terhadap audit delay.

2. Ukuran perusahaan tidak berpengaruh terhadap audit delay.

3. Ukuran KAP berpengaruh signifikan terhadap audit delay.

4. Profitabilitas, ukuran perusahaan dan ukuran KAP secara simultan dapat mempengaruhi audit delay.

\section{DAFTAR PUSTAKA}

Agoes, Sukrisno. AUDITING: Petunjuk Praktis Pemeriksaan Akuntansi oleh Kantor Akuntan Publik (Edisi 5 ed.). Jakarta: Salemba Empat, 2017.

Apriyana, N dan Rahmawati, D. Pengaruh Profitabilitas, Solvabilitas, Ukuran Perusahaan, Dan Ukuran KAP Terhadap Audit Delay pada Perusahaan Properti Dan Real Estate yang Terdaftar di Bursa Efek Indonesia Periode 2013-2015. Jurnal Nominal, Vol.VI, Hal.108-124, 2017.

Arens, Alvin A., Elder, Randal J., dan Beasley, Mark S. Auditing: An Integrated Approach. New Jersey: Prentice Hall Inc., 2017.

Eksandy, A. Pengaruh Ukuran Perushaan, Solvabilitas, Profitabilitas dan Komite Audit Terhadap Audit Delay (Pada Perusahaan Properti dan Real Estate yang Terdaftar di Bursa Efek Indonesia pada Tahun 2012-2015). Competitive Jurnal Akuntansi dan Keuangan, Vol.1, 2017. 
Fadhmi, N., dan Suryani, E. Pengaruh Ukuran Perusahaan, Profitabilitas, dan Solvabilitas Terhadap Audit Delay (Studi Empiris pada Perusahaan Pertambangan yang Terdaftar di Bursa Efek Indonesia Tahun 2012-2016). eProceedings of Management, Vol.5, 2018.

Harahap, S. S. Teori Akuntansi. Jakarta: Rajawali Pers, 2011.

Hastuti, L. P., dan Santoso, S. Pengaruh Solvabilitas, Ukuran KAP, Umur Perusahaan dan Komite Audit Terhadap Audit Delay pada Perusahaan Tekstil dan Garment yang Terdaftar di Bursa Efek Indonesia 2010-2013. Jurnal Penelitian dan Kajian Ilmiah, Vol.15, Hal.27-33, 2017.

Hayes, Rick., Wallage, Philip., dan Gortemaker Hans. Prinsip-Prinsip Pengauditan. Jakarta: Salemba Empat, 2017.

Hery. Teori Akuntansi. Jakarta: Lembaga Penerbit fakultas Ekonomi Universitas Indonesia, 2013.

Ikatan Akuntan Indonesia. Pernyataan Standar Akuntansi Keuangan. Jakarta: Salemba Empat, 2015.

Ghozali, I. Aplikasi Analisis Multivariate dengan Program IBM SPSS 23. Semarang: Badan Penerbit Universitas Diponegoro, 2016.

Kariyoto, Implementasi Value for Money, Input, Output, Outcome dan best Value sebagai alat Pengukuran Hal. 114, 2017.

Kasmir, D. Analisis Laporan Keuangan. Jakarta: Rajawali Pers, 2012.

Keputusan Direksi PT. Bursa Efek Jakarta Nomor: Kep-306/BEJ/07-2004 tentang Peraturan Nomor I-E tentang Kewajiban Penyampaian Informasi

Keputusan Direksi PT. Bursa Efek Jakarta Nomor: Kep-307/BEJ/07-2004 tentang peraturan nomor I-H tentang sanksi.

Kieso, Donal E., Jerry J. Weygandt dan Terry D. Warfield. 2011. Intermediate Accounting edisi IFRS. Jakarta: Erlangga.

Kurniawan, C. Pengaruh Ukuran Perusahaan, Profitabilitas, dan Solvabilitas Terhadap Audit Delay (Studi Empiris pada Perusahaan Perdagangan Eceran yang Terdaftar di Bursa Efek Indonesia Periode 2014 - 2016). Skripsi, 2018.

Lampiran Keputusan Ketua Bapepam dan LK nomor : Kep-346/BL/2011 tanggal 5 Juli 2011.

Liana. Analisis Pengaruh Ukuran Perusahaan, Tingkat Profitabilitas Perusahaan, Opini Auditor dan Kualitas Auditor Terhadap Audit Delay (Studi Empiris Terhadap Perusahaan Industri Dasar dan Kimia yang terdaftar di Bursa Efek Indonesia Tahun 2013 - 2016). Skripsi, 2018.

Lusiana dan Rahma, A. A. Pengaruh Firm Size, Profitability, Audit Committee Size, dan Auditor Opinion Terhadap Audit Delay Pada Perusahaan LQ-45 yang Terdaftar di Bursa Efek Indonesia Tahun 2011-2015. Majalah Ilmiah, Vol.24, Hal.191-205, 2017.

Peraturan Menteri Keuangan Nomor 443/KMK.01/2011Tentang Penetapan Institut Akuntan Publik Indonesia sebagai Asosiasi Profesi Akuntan Publik

Peraturan Pemerintah No. 17 Tahun 2013 Tentang Pelaksanaan Undang-Undang Nomor 20 Tahun 2008 Tentang Usaha Mikro, Kecil, dan Menengah

Peraturan Otoritas Jasa Keuangan Nomor 29/POJK.04/2016 Tentang Laporan Tahunan Emiten atau Perusahaan Publik

Ratnasari, S. N., \& Yennisa. Pengaruh Ukuran Perusahaan, Ukuran KAP dan Auditor Internal Terhadap Audit Delay pada Perusahaan Manufacture Sektor Consumer Goods (20122015). Jurnal Akuntansi, Vol.5, Hal.159-166, 2017.

Simatupang, L., Putra, W. E., \& Herawaty, N. Perbandingan Pengaruh Ukuran Perusahaan, Opini Audit, Profitabilitas dan Reputasi KAP Terhadap Audit Delay pada Perbankan 
Konvensional dan Perbankan Syariah (2014-2016). Jurnal Riset Akuntansi dan Keuangan, Vol.6, Hal.45-62, 2018.

Sugiyono, P. D. Metode Penelitian Kuantitatif, Kualitatif, dan R\&D. Bandung: Alfabeta, 2012.

Sujarweni, V. Wiratna. Statistik untuk Bisnis dan Ekonomi. Yogyakarta: BPFE Yogyakarta, 2015.

Syah, E. S. Pengaruh Solvabilitas, Kepemilikan Publik, Auditor Switching dan Perusahaan Holding Terhadap Audit Delay (2011-2014). JOM Fekon, Vol.4, Hal.1801-1812, 2017.

Undang-Undang Republik Indonesia Nomor 5 Tahun 2011 tentang Akuntan Publik

Undang-Undang Republik Indonesia Nomor 8 Tahun 1995 Tentang Pasar Modal

Undang-undang Republik Indonesia Nomor 20 tahun 2008 tentang Usaha Mikro, Kecil, dan Menengah.

Warren, C. S. Accounting Pengantar Akuntansi. Jakarta: Salemba Empat, 2008.

Widyastuti, M. T., \& Astika, I. B. Pengaruh Ukuran Perusahaan, Kompleksitas Operasi Perusahaan dan Jenis Industri Terhadap Audit Delay pada Perusahaan Perbankan dan Consumer Goods Industry (2011-2014). E-Jurnal Akuntansi, Vol.18, Hal.1082-1111, 2017.

Zwaztiana, T., \& Suzan, L. Pengaruh Ukuran Perusahaan, Kualitas Kantor Akuntan Publik dan Return On Asset Terhadap Audit Delay (Studi pada Perusahaan Sektor Property, Real Estate, dan Konstruksi Bangunan yang Terdaftar di Bursa Efek Indonesia Tahun 2012-2016). e-Proceeding of Management, Vol.5, Hal.828-834, 2018 